\title{
JENIS-JENIS ALGA COKLAT POTENSIAL DI PERAIRAN PANTAI DESA HUTUMURI PULAU AMBON
}

\author{
Inem Ode dan Jahra Wasahua \\ Staf Pengajar FPIK UNIDAR-Ambon, e-mail: -
}

\begin{abstract}
ABSTRAK
Pemanfaatan alga untuk berbagai keperluan industri sangat tergantung pada senyawa penting di dalamnya, sifat fisik, dan sifat kimia senyawa tersebut. Phaeophyceae (alga coklat) mengandung alginat, protein, vitamin $C$, tannin, iodine, phenol sebagai obat gondok, anti bakteri dan tumor. Penelitian ini bertujuan untuk mengetahui jenis-jenis alga coklat potensial di perairan pantai desa Hutumuri, Pulau Ambon. Penelitian ini diharapkan dapat bermanfaat bagi pengembangan pemanfaatannya alga coklat. Penelitian ini dilakukan pada bulan Juni 2014. Pengambilan sampel alga coklat dilakukan dengan cara koleksi bebas pada saat surut, pada saat pengambilan sampel diamati secara visual kondisi substrat tempat tumbuh alga coklat. Pada saat pengambilan sampel alga coklat juga dilakukan pengukuran parameter lingkungan fisika-kimia perairan di beberapa titik yang mewakili lokasi penelitian yang meliputi suhu, salinitas, $p H$, kecepatan arus, Nitrat dan Phospat. Dari hasil sampling dan determinasi alga coklat di perairan pantai Hutumuri ditemukan tujuh jenis alga coklat. Enam diantaranya teridentifikasi sampai tingkat spesies yakni Sargassum crassifolium, Sargassum vulgare, Sargassum cinereum, Hormophysa cuneiformis, Turbinaria ornata, Padina Australis dan satu jenis tidak teridentifikasi. Keenam jenis alga coklat yang ditemukan memiliki potensi sebagai sumber alginat, obat-obatan, bioindikator logam berat, sumber makanan dan pupuk.
\end{abstract}

Kata Kunci: Alga coklat potensial, Phaeophyceae, rumput laut, desa Hutumuri

\section{PENDAHULUAN}

\subsection{Latar Belakang}

Salah satu sumberdaya hayati laut yang sangat potensial untuk dikembangkan karena memiliki nilai ekonomis tinggi adalah alga laut, yang juga dikenal di masyarakat dengan nama rumput laut (seaweed). Rumput laut telah lama dimanfaatkan oleh masyarakat pesisir sebagai sumber makanan dengan mengkonsumsinya secara langsung, dan diproses menjadi berbagai pangan olahan. Dengan kemajuan ilmu pengetahuan dan teknologi, rumput laut diketahui mengandung senyawa hidrokoloid, senyawa bioaktif dan senyawa penting lainnya. Dunia industri telah mengolah rumput laut menjadi sekitar 500 jenis produk olahan dan berhasil dikembangkan secara komersial seperti agar-agar, puding, kosmetik, pasta gigi, shampo, kertas, tekstil, dan pelumas pada pegeboran sumur minyak (Wiyadstuti, 2009).

Pemanfaatan alga untuk berbagai keperluan industri sangat tergantung pada senyawa penting di dalamnya, sifat fisik, dan sifat kimia senyawa tersebut. Alga dibagi kedalam tiga kelas besar, yaitu Rhodophyceae (alga merah), Phaeophyceae (alga coklat), Chlorophyceae (alga hijau). Rhodophyceae (alga merah) mengandung karagenan dan agar, sehingga banyak dimanfaatkan dalam berbagai industri seperti pangan, kimia dan obat-obatan (Istini et al, 2008). Phaeophyceae (alga coklat) mengandung alginat atau algin merupakan senyawa hidrokoloid. Secara kimiawi, senyawa alginat merupakan suatu polimer panjang yang disusun oleh dua unit monomerik, yaitu $\beta$-Dmannuronic acid dan $\alpha$-L-guluronic acid (Draget et al, 2005). 
Pemanfaatan alginat didasarkan pada tiga sifat utamanya yaitu yang pertama kemampuannya dalam menaikan viscositas larutan apabila alginat dilarutkan dalam air. Kedua adalah kemampuan alginat untuk membentuk gel, dan ketiga adalah kemampuan alginat membentuk film dari natrium atau kalsium alginat dan fiber dari kalsium alginat. Alginat menjadi sangat penting karena penggunaannya yang cukup luas dalam industri. Alginat banyak digunakan pada industri kosmetik untuk membuat sabun, cream, lotion, shampo, dan pencelup rambut. Industri farmasi memerlukannya untuk pembuatan suspensi, emulsifier, stabilizer, tablet, salep, kapsul, plester, dan filter. Industri makanan merupakan salah satu pengguna terbesar alginat disamping industri lainnya yaitu karet, tekstil, keramik, minuman, dan cat. Sifat toksik alginat telah diteliti secara ekstensif dan telah ditetapkan bahwa alginat aman untuk digunakan pada makanan (Mc. Hugh, 2003).

Alga coklat selain mengandung alginat juga mengandung protein, vitamin $\mathrm{C}$, tannin, iodine, phenol sebagai obat gondok, anti bakteri dan tumor. Beberapa penelitian mengungkap aktivitas antikanker senyawa fucoidan pada alga coklat. Fucoidan memiliki beberapa khasiat farmakologi seperti sebagai antikoagulan, antitrombolitik, antitumor, antivirus, imunomodulator, antioksidan, reduksi lemah darah, antikomplemen, antiinflamasi, perlindungan pencernaan, melawan hepatopaty, uropaty,renalpaty (Angka dan Suhartono 2000).

Di perairan Indonesia terdapat sekitar 28 spesies alga coklat yang berasal dari enam genus yakni Dyctyota, Sargassum, Padina, Hormophysa, Turbinaria, dan Hydroclathrus. Spesies rumput laut yang telah diidentifikasi yaitu Sargassum sp sebanyak 14 spesies, Turbinaria sebanyak 4 spesies, Hormophysa baru 1 spesies, Padina 4 spesies, Dyctyota 5 spesies dan Hydroclathrus 1 spesies.

\subsection{Tujuan Penelitian}

Penelitian ini bertujuan untuk mengetahui jenis-jenis alga coklat potensial di perairan pantai desa Hutumuri, Pulau Ambon.
Penelitian ini diharapkan dapat bermanfaat bagi pengembangan pemanfaatan alga coklat.

\section{METODE PENELITTIAN}

Penelitian ini dilakukan pada bulan Juni 2014. Pengambilan sampel alga coklat dilakukan dengan cara koleksi bebas pada saat surut, pada saat pengambilan sampel diamati secara visual kondisi substrat tempat tumbuh alga coklat. Pada saat pengambilan sampel alga coklat juga dilakukan pengukuran parameter lingkungan fisika-kimia perairan di beberapa titik yang mewakili lokasi penelitian yaitu suhu dengan menggunakan thermometer batang, salinitas dengan menggunakan handrefraktometer, derajat keasaman $(\mathrm{pH})$ menggunakan $\mathrm{pH}$ meter, kecepatan arus menggunakan stop watch dan layangan arus. Pengukuran suhu, salinitas, $\mathrm{pH}$, kecepatan arus dilakukan in-situ. Untuk posfat $\left(\mathrm{PO}_{4}\right)$ dan nitrat $\left(\mathrm{NO}_{3}\right)$ sampel air diambil di lokasi penelitian dengan menggunakan botol gelap, kemudian dianalisa menggunakan spektrofotometer di laboratorium LIPI Ambon. Jenis alga coklat yang didapat dideterminasi dengan pustaka acuan Bhavanath et al, (2009); Chapman and Chapman, (1980); Codero (1980) ; Magruder (1979) dan dianalisis secara deskriptif ciri-ciri morfologinya.

\section{HASIL DAN PEMBAHASAN}

\subsection{Jenis-jenis Alga Coklat}

Substrat yang mendominasi perairan pantai Hutumuri adalah substrat berbatu, dan pasir bercampur patahan karang mati. Substrat merupakan salah satu komponen terpenting dalam keberadaan dan pertumbuhan jenis rumput laut. Bold (1985) dalam Indrawati (2009) menyatakan bahwa rumput laut merupakan makro bentos yang tumbuh melekat pada berbagai jenis tipe substrat seperti lumpur atau pasir, pada batu-batuan atau karang, dengan kata lain pada kondisi atau tipe substrat yang sesuai suatu jenis rumput laut ditemukan melimpah. Rumput laut merupakan tumbuhan berklorofil yang hidup dengan melekatkan diri pada substrat perairan menggunakan holdfast sehingga rumput laut tidak mudah berpindah oleh gerakan air. Rumput laut banyak tumbuh di daerah pasang surut yang perairannya jernih 
dan menempati substrat tertentu yang sesuai dengan kehidupannya (Kadi, 2006).

Dari hasil sampling dan determinasi alga coklat di perairan pantai Hutumuri ditemukan tujuh jenis alga coklat. Enam diantaranya teridentifikasi sampai tingkat spesies yakni
Sargassum crassifolium, Sargassum vulgare, Sargassum cinereum, Hormophysa cuneiformis, Turbinaria ornata, Padina Australis dan satu jenis tidak teridentifikasi Gambar 1.

Klasifikasi alga coklat yang ditemukan selama penelitian dapat dilihat pada Tabel 1.

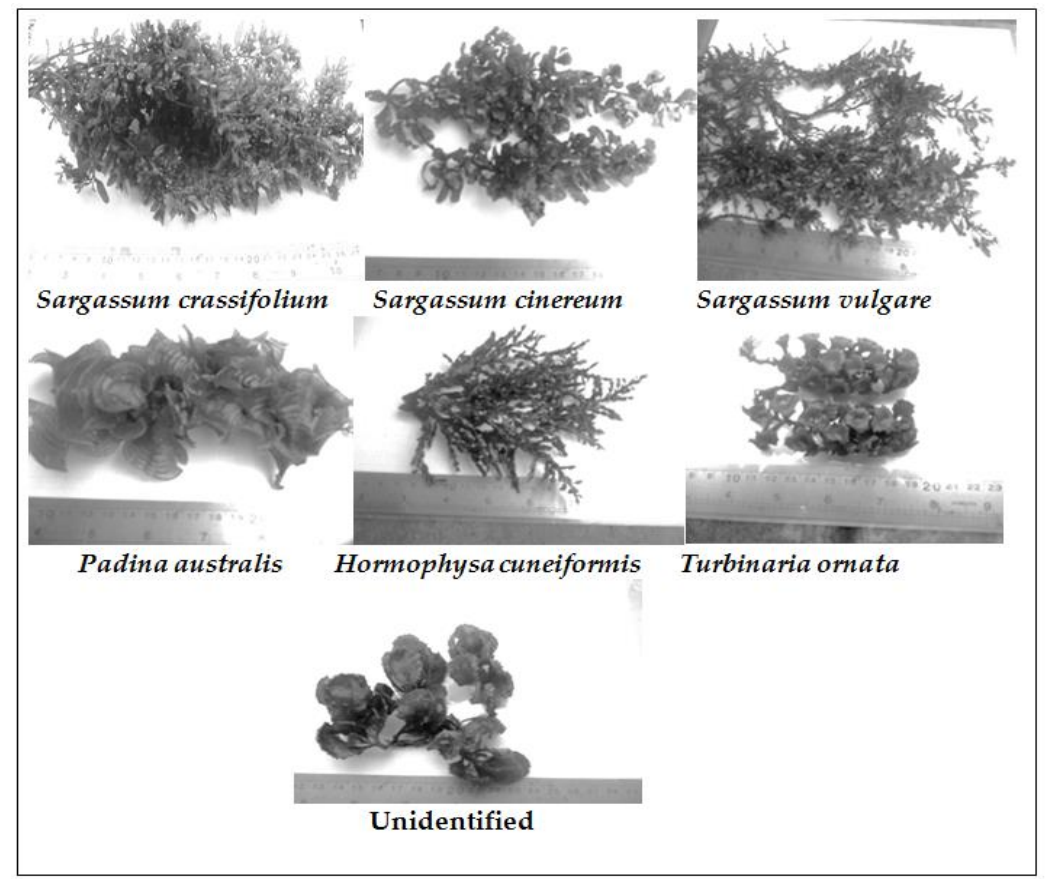

Gambar 1. Jenis - jenis Alga Coklat di Perairan Pantai Hutumuri

Tabel 1. Klasifikasi Alga Coklat

\begin{tabular}{cllll}
\hline Kelas & Ordo & \multicolumn{1}{c}{ Famili } & \multicolumn{1}{c}{ Genus } & \multicolumn{1}{c}{ Spesies } \\
\hline Phaeophyceae & Dictyotales & Dictyotaceae & Padina & australis \\
& Fucales & Sargassaceae & Sargassum & crassifolium \\
& & & cinereum \\
& & & vulgare \\
& & Hormophysa & cuneiformis \\
& & & Turbinaria & ornata \\
\hline
\end{tabular}

Widiyastuti (2009), alga coklat memiliki thallus berwarna coklat yang bervariasi dari coklat tua sampai coklat muda. Bentuk thallus alga coklat beranekaragam, ada yang silindris, gepeng dan banyak juga yang berbentuk lembaran. Berdasarkan bentuk thallusnya, alga coklat merupakan kelas Thallophyta yang menyerupai tumbuhan tingkat tinggi, karena organ thallusnya menyerupai akar, batang dan daun. Genus Sargassum hidup pada bongkahan batu karang, warnanya bermacam-macam dari coklat muda sampai coklat tua. Alat pelekatnya terdiri dari cakram pipih, dari cakram ini muncul tangkai yang pendek silindrik yang tegak. Dari tangkai yang pendek ini muncul poros-poros silindrik panjang. Masing-masing poros ini dapat mencapai 1 meter panjangnya di mintakat bawah litoral dimana Sargassum hidup. Pada poros yang silindrik dengan diameter $3 \mathrm{~mm}$ terdapat bentuk-bentuk seperti daun, kantung udara dan cabang-cabang perkembangbiakan (Romimohrarto dan Juwana, 2007). Dilokasi penelitian terdapat 3 jenis yakni Sargassum crassifolium, Sargassum cinereum, dan Sargassum vulgare

Hormophysa cuneiformis, Ciri-ciri umum thallus tegak, rimbun, alat pelekat seperti cakram dan rhizoid pendek, bagian pangkal thalli menyerupai tangkai, warna coklat tua. Sepanjang sumbu tegak dan cabang-cabanya, 
pada kedua sisinya terdapat semacam 'sayap' yang bentuknya tidak teratur, hidup menempel pada batu dengan alat pelekatnya berbentuk cakram kecil. Alga ini hidup bercampur dengan Sargassum dan Turbinaria (Bhavanath et al. 2009).

Turbinaria, memiliki thallus foloid yang bentuknya menyerupai turbin, memiliki gerigi pada pinggirannya yang bervariasi tergantung spesiesnya (Widiyastuti, 2009). Turbinaria mempunyai cabang-cabang silindrik dengan diameter 2-3 $\mathrm{mm}$, dan mempunyai cabang lateral pendek dari $1-1,5 \mathrm{~cm}$ panjangnya. Ini berakhir pada sebuah reseptakel dengan pinggiran bergerigi dan garis tengahnya kira-kira $1 \mathrm{~cm}$ (Magruder, 1979)

Codero (1980), Padina australis menunjukkan ciri utama yaitu thalli berukuran besar (sekitar $15 \mathrm{~cm}$ ), membentuk kipas dengan lebar $2-8 \mathrm{~cm}$, dan terdapat segmen-segmen lembaran tipis (lobus) dengan garis-garis berambut radial. Thalus Padina australis tersusun dari epidermis dan sel parenkim. Ukuran lembaran thalus yaitu $5-10 \mathrm{~cm}$ dan bersifat mudah robek. Warna utama adalah coklat muda kekuning-kuningan, tetapi terkadang warnanya memutih karena adanya perkapuran di permukaan daun. Bagian atas lobus agak melebar dengan pinggiran rata dan holdfast berbentuk cakram kecil berserabut Chapman and Chapman, 1980). Padina memiliki thallus berbentuk lembaran yang menyerupai kipas. (Romimohtarto dan Juwana, 2007) Padina tumbuh menempel di batu pada daerah rataan terumbu, alat pelekatnya terdiri dari cakram pipih, biasanya terbagi menjadi cuping-cuping pipih.

\subsection{Parameter Lingkungan}

Parameter fisika-kimia lingkungan perairan yang terukur di lokasi penelitian dapat dilihat pada Tabel 2.

Tabel 2. Parameter Lingkungan di Lokasi Penelitian

\begin{tabular}{lc}
\hline \multicolumn{1}{c}{ Parameter Lingkungan } & Nilai \\
\hline Suhu & $29-30^{\circ} \mathrm{C}$ \\
Salinitas & $33-34 \mathrm{ppt}$ \\
$\mathrm{pH}$ & $8,4-8,5$ \\
Kecepatan Arus & $8,3-11,1 \mathrm{~cm} / \mathrm{det}$ \\
Phosfat $\left(\mathrm{PO}_{4}\right)$ & $0,0058-0,0069 \mathrm{ppm}$ \\
Nitrat $\left(\mathrm{NO}_{3}\right)$ & $0,0061-0,0093 \mathrm{ppm}$ \\
\hline
\end{tabular}

Kisaran suhu selama penelitian berkisar antara $29-30{ }^{\circ} \mathrm{C}$. Suhu lingkungan berperan penting dalam proses fotosintesa, dimana semakin tinggi intensitas matahari dan semakin optimum kondisi temperatur, maka akan semakin nyata hasil fotosintesanya (Lee, 1999). Menurut (Afrianto dan Liviawati, 1993) meskipun temperatur tidak mematikan namun dapat menghambat pertumbuhan rumput laut. Pada umumnya rumput laut tumbuh dengan baik di daerah yang mempunyai kisaran suhu sekitar $26-33^{\circ} \mathrm{C}$.

Salinitas yang diperoleh selama penelitian berkisar antara $33-34$ ppt. Salinitas merupakan salah satu faktor yang mempengaruhi pertumbuhan rumput laut. Kondisi salinitas yang baik untuk pertumbuhan rumput laut yaitu berkisar antara 15-34 ppt (Zatnika, 2009). Menurut Choi et al., dalam Umasugi (2001), rumput laut akan mengalami pertumbuhan yang lambat, apabila salinitas terlalu rendah (15 ppt) atau terlalu tinggi (35 ppt), lebih lanjut dikatakan bahwa perbedaan salinitas mempengaruhi mekanisme fisiologi dan biokimia rumput laut sebab proses perubahan tekanan osmosis berkaitan erat dengan peran membran sel dalam proses transfor nutrien.

Hasil pengukuran $\mathrm{pH}$ di lokasi penelitian berkisar antara $8,4-8,5$. Pertumbuhan rumput laut memerlukan $\mathrm{pH}$ air laut optimal yang berkisar antara 6-9 (Zatnika, 2009). Chapman (1962) dalam Supit (1989) menyataka bahwa hampir seluruh rumput laut menyukai kisaran pH 6,8 - 9,6. Sehingga variasi pH yang tidak terlalu besar tidak akan menjadi masalah bagi pertumbuhan rumput laut. Zulbainarmi (1997) dalam Umasugi (2001), menyatakan bahwa rumput laut tumbuh pada kisaran $\mathrm{pH}$ 6,5 - 8,5 keadaan $\mathrm{pH}$ yang sesuai sangat berpengaruh terhadap pertumbuhan dan kualitas serta kuantitas dari rumput laut itu sendiri. Hal ini mengoptimalkan sistem metabolisme dari rumput laut yang mana dalam hal ini, pembentukan biomassa terhalang oleh aktivitas dari rumput laut yang menggunakan energi untuk menstabilkan kondisi jaringannya karena adanya perubahan $\mathrm{pH}$ yang tidak ideal untuk pertumbuhannya.

Kecepatan arus di suatu perairan merupakan faktor yang dapat mempengaruhi 
dan mengontrol pertumbuhan rumput laut. Selain dapat menyediakan nutrien bagi rumput laut, arus juga dapat mengontrol peningkatan suhu air (Radiarta et al, 2007 dalam Tiensongrusmee, 1990). Pengaruh arus cukup besar dalam menghalau sisa-sisa metabolisme atau limbah, percampuran dan penyebaran nutrien serta gas-gas. Oleh karena itu, arus dapat dijadikan sebagai indikator tingginya laju produktivitas perairan. Selain itu, kenaikan kecepatan arus meningkatkan proses fotosintesis, tetapi pada level tertentu laju fotosintesis tetap (Supriharyono, 2008). Menurut Mubarak (1981) kecepatan arus yang optimal bagi pertumbuhan rumput laut di suatu perairan pantai berkisar antara $20-40$ $\mathrm{cm} /$ detik. Kecepatan arus yang terukur pada saat pengambilan sampel alga coklat berkisar antara yaitu $8,3-11,1 \mathrm{~cm} /$ det.

Masrawati (1998), menjelaskan bahwa unsur fosfor dan nitrogen diperlukan rumput laut bagi pertumbuhannya dan umumnya unsur fosfor yang diserap oleh alga adalah ortofosfat sedangkan nitrogen diserap dalam bentuk nitrit, nitrit maupun amonium. Kandungan phosfat dalam perairan berkisar antara 1-60 ppm dan kisaran nitrat yang baik di lautan bagi kehidupan organisme nabati adalah sekitar 0,01 - 5 ppm (Alam, 2011). Kandungan phosfat di lokasi penelitian berkisar antara 0,0058-0,0069 ppm sedangkan nitrat berkisar antara 0,0061-0,0093 ppm. Kisaran ini sangat rendah dibanding kisaran rata-rata untuk pertumbuhan alga. Menurut Dawes (1974) dalam Masrawati (1998) bahwa zat hara bagi rumput laut / alga diperoleh dari air sekelilingnya dimana penyerapannya dilakukan melalui seluruh bagian tanaman. Selain itu ketersediaan zat hara tidak menjadi faktor penghambat pertumbuhan rumput laut, artinya zat hara yang ada dilaut masi cukup bahkan berlebihan untuk kehidupan rumput laut. Hal ini dapat terjadi karena adanya sirkulasi yang baik, run off dari daratan dan gerakan air.

\subsection{Potensi Jenis Alga Coklat}

Empat genus alga coklat yang ditemukan di perairan pantai desa Hutumuri yakni Sargassum, Hormophysa, Padina dan Turbinaria, menurut beberapa pustaka memiliki potensi yang dapat dikembangkan yakni sebagai sumber alginat, obat-obatan, bioindikator logam berat, sumber makanan dan pupuk.

Hasil fotosintesis yang bernilai ekonomis tinggi dan dapat diekstraksi dari alga coklat adalah Alginat, yaitu garam dari asam alginat yang mengandung ion sodim (natrium), kalium dan kalsium (Kadi dan Atmadja, 1988). Alginat dimanfaatkan karena sifat garamnya yang larut di dalam air dan membentuk larutan kental yang berkenaan dengan fungsinya sebagai pengental, pemantap suspensi, pengemulsi dan pembentuk film. Di dalam industri pangan, alginat digunakan dalam es krim, lapisan gula pada kue, di dalam saus dan bumbu salad, anggur, bir, sari buah, masakan daging. Di dalam detergen, alginat dapat berfungsi sebagai penstabil busa (Angka dan Suhartono, 2000). Menurut (Rasyid (2007), di Indonesia ditemukan alga coklat yang berpotensi sebagai penghasil alginat (alginofit) yaitu Sargassum sp, Turbiaria sp, Hormophysa sp, dan Padina sp. Menurut (Angka dan Suhartono, 2000) Alga coklat penghasil alginat (alginofit) yang paling banyak penyebarannya diperairan Indonesia adalah spesies dari marga Sargassum dan disusul dari marga Turbinaria.

Padina diketahui mempunyai aktivitas antibakteri, Sargassum diketahui mempunyai aktivitas antibakteri, antitumor, menurunkan tekanan darah tinggi dan gangguan kelenjar gondok (Atmadja et al. 1990). Angka dan Suhartono (2000), melaporkan bahwa Sargassum sp mampu mensistesis 2 jenis fucoidan. Fucoidan memiliki beberapa khasiat farmakologi seperti sebagai antikoagulan, antitrombolitik, antitumor, antivirus, imunomodulator, antioksidan, reduksi lemah darah, antikomplemen, anti inflamasi, perlindungan pencernaan, melawan hepatopaty, uropaty, renalpaty.

Sargassum merupakan spesies alga yang potensial sebagai bioindikator logam berat $\mathrm{Pb}$, Cd, Cu (Bachtiar, 2007). Alga dapat dimanfaatkan sebagai bioindikator logam berat karena dalam proses pertumbuhannya, alga membutuhkan sebagian jenis logam sebagai nutrien alami, sedangkan ketersediaan logam di lingkungan sangat bervariasi. Suatu lingkungan yang memiliki kandungan logam 
berat melebihi jumlah yang diperlukan, dapat mengakibatkan pertumbuhan alga menjadi terhambat.

Alga coklat Sargassum crassifolium memiliki kadar vitamin A (489,55 RE/100 g) dan vitami C (49,01 mg/100 g), kadar ini terletak diantara rentangan vitamin $A$ dan vitamin $C$ sayuran pada umumnya sehingga alga ini dapat digunakan sebagai makanan sumber vitamin A dan Vitamin C (Handayani dkk, 2004).

Alga coklat Padina australis, Sargassum sp dan Turbinaria sp dapat dimanfaatkan sebagai pupuk tanaman karena mengandung zat tumbuh dan berbagai jenis mineral dari laut yang berguna bagi kesuburan tanah dan mempercepat laju pertumbahan tanaman (Winarno, 1991) ; Angka dan Suhartono (2000). Alga dapat dimanfaatkan sebagai pupuk organik karena mengandung bahan-bahan mineral seperti potasium dan hormon seperti auxin dan sytokinin yang dapat meningkatkan daya tumbuh tanaman untuk tumbuh, berbunga dan berbuah. Pemanfaatan alga sebagai pupuk organik ditunjang oleh adanya sifat hydroccoloids pada alga laut yang dapat dimanfaatkan untuk penyerapan air (daya serap tinggi) dan menjadi substrat yang baik bagi mikroorganisme tanah (Bachtiar, 2007).

\section{PENUTUP}

\section{Kesimpulan}

1. Di perairan pantai Hutumuri terdapat enam jenis alga coklat yakni Sargassum crassifolium, Sargassum vulgare, Sargassum cinereum, Hormophysa cuneiformis, Turbinaria ornata, dan Padina australis.

2. Keenam jenis alga coklat yang ditemukan memiliki potensi sebagai sumber alginat, obat-obatan, bioindikator logam berat, sumber makanan dan pupuk.

Saran

Perlu dilakukan kajian yang lebih mendalam kaitannya dengan potensi alga coklat sehingga dapat dikembangkan pemanfaatannya.

\section{DAFTAR PUSTAKA}

Afrianto dan Liviawati, 1993. Budidaya Rumput Laut dan Cara Pengolahannya, Penerbit Bharata. Jakarta

Alam, A. 2011. Kualitas Karagenan Rumput Laut Jenis Eucheuma spinosum Di Perairan Desa Punaga, Kabupaten Takalar. Thesis Jurusan Ilmu Kelautan, Fakultas Ilmu Kelautan Dan Perikanan. Universitas Hasanudin Makassar.

Anggadiredja, JT, A. Zatnika, H. Purwoto dan S. Istini. 2008. Teknologi Pemanfaatan Rumput Laut. Jurnal Penelitian Perikanan Indonesia. Badan Riset Kelautan dan Perikanan Departemen Kelautan dan Perikanan. Jakarta.

Angka dan Suhartono, 2000. Bioteknologi Hasil Laut. Pusat Kajian Sumberdaya Pesisisr dan Lautan. IPB.Bogor.

Bachtiar, E., 2007. Penelusuran Sumberdaya Hayati Laut (alga) sebagai Biotarget Industri. Makalah. Fakultas Perikanan dan Ilmu Kelautan Unpad, Jatinangor.

Bhavanath, Jha., C.R.K. Reddy, C.T. Mukund., 2009. Seaweed of India. The Diversity and Distribution of Seaweed of the Gujarat Coast.

Chapman, V.J and D.J Chapman, 1980. Seaweed and Their Uses. Third Edition, Newwork.

Codero, P.A.J.,1980. Taxonomy and Distribution of Philiphine useful seaweed. National Research Council of the Philiphines. Metro Manila Philiphines.

Draget, K. I. Philips and P. A. Williams. 2005. Alginates. Handbook of Hydrocolloids. edited by G. O. CRC Press.379-395.

Handayani, Sutarno, A.D. Setyawan, 2004. Analisis komposisi nutrisi rumput laut Sargassum crassifolium J. Agardh. Biofarmasi 2 (2) : 45-52. ISSN :1693-2242.

Indrawati, 2009 Seaweed (http://ilove marine biru lautku. blogspot. com/2011/12/seaweed. html.).Di akses 9 Juli 2014. 
Kadi, A. 2006. Beberapa Catatan Kehadiran Marga Sargassum di Perairan Indonesia. Jurnal Oseana, 4: 19-29.

Lee. 1999, Kondisi Lingkungan yang Mempengaruhi Budidaya RumputLaut http://informasibudidaya.blogspot.com/2010/01/kondisi-lingkungan-yang-mempengaruhi.html. Di akses 6 Juli 2014

Masrawati. 1998. Struktur Komunitas Rumput Laut di Taman Wisata Alam Laut Gili Air- Meno Trawangan Lombok, Nusa Tenggara Barat. Skripsi Fakultas Perikanan IPB. Bogor.

Mc. Hugh, D.J. 2003. A guide to seaweed industry. FAO Fisheries Technical Paper 441. Food and agriculture organization of the the Inited Nations, Rome : 105 pp

Mubarak, 1981. Budidaya Rumput Laut. Materi Lokakarya Budidaya Laut di Denpasar. Dirjen Perikanan dan UNDP/FAO. 12 hal

Magruder, W.H. 1979. Seaweed Of Hawai. The Oriental Publishing Company PO.Box 22162. Honolulu, Hawai.

Rasyid, A. 2007. Ekstraksi Natrium Alginat Dari Padina australis. Jurnal Oseanologi dan Limnologi di Indonesia. 33 : 271-279

Romimohtarto dan Juwana, 2007. Biologi Laut. Edisi revisi, Djambatan. Jakarta

Supit, 1989. Karakteristik Pertumbuhan dan Kandungan Karaginan Rumput Laut Eucheuma alvarezii Yang Berwarna Abu-abu, Coklat dan Hijau Yang Ditanam Di Goba Labangan Pasir Pulau Pari. Karya Ilmiah. Fakultas Perikanan IPB Bogor.

Supriharyono, 2008. Seaweed (http://seaweed.html). Di akses 9 Juli 2014

Tiensongrusmee, 1990. Seaweed (http://seaweed.html.).Di akses 9 Juli 2014

Umasugi, R 2001, Kepadatan, pola distribusi dan keanekaragaman rumput laut di perairan pantai Desa tanjung tiram kecamatan Moramo Kabupaten kendari. Skripsi progaram studi Manajemen Sumber daya perairan Universitas Haluoleo Kendari.

Widyastuti, 2009. Kadar Alginat Rumput Laut yang Tumbuh Di Perairan Lombok yang Diekstrak Dengan Dua Metode Ekstraksi. Jurnal Teknologi Pertanian. Vol. 10, No. 3 Fakultas Pertanian, Universitas Mataram.

Zatnika, 2009. Rumput laut (www.google.com/search). Di akses 4 Juli 2014. 